\title{
The efficiency engine - cost-effective alternative to downsizing
}

\author{
As an alternative to the familiar option of downsizing diesel engines, AVL has developed the so-called efficiency engine \\ in collaboration with Renault. Because of the engine's moderate power density, its peak pressure requirements are lower \\ in some areas than those of turbocharged gasoline engines. Consequently, its mechanical friction and fuel consumption \\ can be significantly reduced, as the comparison with a conventional and a downsized diesel engine demonstrates. \\ Key words: engine efficiency, fuel consumption, engine concepts, downsizing
}

\section{Wysokosprawny silnik - korzystna alternatywa dla downsizingu}

Firma AVL, przy wspótpracy z koncernem Renault, rozwinęła tzw. wysokosprawny silnik, jako rozwiazanie alternatywne dla znanej koncepcji downsizingu silników ZS. Z uwagi na umiarkowany objętościowy wskaźnik mocy silnika, maksymalne wartości ciśnienia w silniku sa mniejsze w niektórych obszarach niż te dla turbodoładowanych silników ZI. $W$ wyniku tego moga być zmniejszone straty tarcia i zużycie paliwa, w porównaniu do konwencjonalnych $i$ poddanych procesowi downsizingu silników ZS.

Słowa kluczowe: sprawność silnika, zużycie paliwa, koncepcje silników, downsizing

\section{Reduced friction and fuel consumption}

Reduction of fuel consumption and costs dominate the future market requirements in drive train development. Alongside electrification, downsizing concepts currently play a major role in $\mathrm{CO}_{2}$ reduction. However, this route means a further cost increase for the diesel engine in order to offer acceptable performance in heavy vehicles using engines with reduced displacement. Main cost drivers are the modified fuel injection and boosting-system for increased specific power density as well as the higher efficiency requirement for the $\mathrm{NO}_{x}$ aftertreatment system. An attractive alternative to a classical downsizing concept is an efficiency-engine concept, optimized for a more moderate power density and minimized frictional losses. In this case, instead of reducing swept volume, the specific power density is reduced to $45 \mathrm{~kW} / 1$ in the first generation, thus covering the needs of the high volume market. For this moderate power density the required peak firing pressure is reduced to a value even lower than those of some turbocharged gasoline engines. With a consequent modular redefinition of the crank train the friction can be significantly reduced, achieving a $\mathrm{CO}_{2}$ reduction corresponding to a swept volume reduction by 20 to $25 \%$. In this paper the details of such an efficiency engine concept (DDE: Derated Diesel Engine) will be discussed in comparison to a typical downsizing concept (ADD: Aggressive Downsized Diesel) [1].

\section{Selection of engine swept volume versus power density}

In this article the selection of engine size for a given vehicle definition is made considering different driving cycles since the NEDC (New European Driving Cycle) will be replaced by the WLTP (Worldwide Harmonized

\section{Zmniejszone straty tarcia i zużycie paliwa}

Redukcja zużycia paliwa i zmniejszenie kosztów dominują jako przyszłe wymagania rynkowe w rozwoju zespołu napędowego. Obok zastosowania napędów elektrycznych, koncepcje bazujące na downsizingu silnika odgrywają główną rolę w redukcji emisji $\mathrm{CO}_{2}$. To jednak oznacza dalszy wzrost kosztów dla silnika ZS w celu zaoferowania akceptowalnych osiągów dla silników pojazdów HDV o zredukowanej objętości skokowej. Głównymi czynnikami decydującymi o kosztach są zmodyfikowany wtrysk paliwa i system doładowania, niezbędne dla zwiększonej jednostkowej mocy użytecznej, jak również większe wymagania w zakresie skuteczności redukcji katalitycznej $\mathrm{NO}_{x}$.

Atrakcyjną alternatywą dla klasycznej koncepcji downsizingu jest koncepcja wysokosprawnego silnika, zoptymalizowanego dla bardziej umiarkowanego zapotrzebowania na moc i o zminimalizowanych stratach tarcia. W tym przypadku zamiast redukcji objętości skokowej, obniżono stopień wysilenia silnika (objętościowy wskaźnik mocy) do wartości $45 \mathrm{~kW} / \mathrm{dm}^{3}$ dla pierwszej generacji, co pokrywa zapotrzebowania rynku pojazdów typu HDV. Dla tego umiarkowanego wysilenia, wymagane maksymalne ciśnienie spalania jest zmniejszone nawet do wartości mniejszej niż uzyskiwana dla niektórych turbodoładowanych silników ZI. Przez zaprojektowanie nowego układu korbowo-tłokowego można zmniejszyć znacząco straty tarcia, uzyskując zmniejszenie emisji $\mathrm{CO}_{2}$ odpowiadające redukcji objętości skokowej o $20-25 \%$. W pracy przeanalizowano szczegóły koncepcji wysokosprawnego silnika (DDE-Derated Diesel Engine) na tle typowej koncepcji downsizingu silnika ZS (ADD - Aggressive Downsized Diesel) [1]. 
Light Vehicles Test Procedure) cycle. The final definition of the new cycle was not available at the time this paper was written, so a test procedure with more focus on higher load and considering more transients than the NEDC was defined for the simulations, thus covering the expected trend for the new cycle definition. The comparison starts with the internally named F9Q 1.91 engine which was quite typical for this vehicle class (Renault Laguna) in the recent past. The DDE efficiency engine is based on a Renault K9K engine (1.46 l) as described in detail in the next chapter, while the downsizing concept (ADD) is represented by a 1.051 threecylinder engine with $80 \mathrm{~kW}$. This downsizing concept was also defined for Renault and has already been presented in detail in a publication [2].

The results of this comparative vehicle simulation can be seen in Fig. 1. The already existing K9K with 1.461 swept volume serves as base for this relative comparison. All listed percentage changes relate to this engine size. In Fig. 1 (top left) the NEDC results are listed. Applying the efficiency engine with reduced friction, the fuel consumption can be reduced by $5.3 \%$ while soot and $\mathrm{NO}_{\mathrm{x}}$ emissions are reduced by 4.3 or $6.1 \%$ respectively while keeping the swept volume constant. With the 1.051 engine the fuel consumption decreases by $8.2 \%$ while $\mathrm{NO}_{\mathrm{x}}$ and soot emissions increase
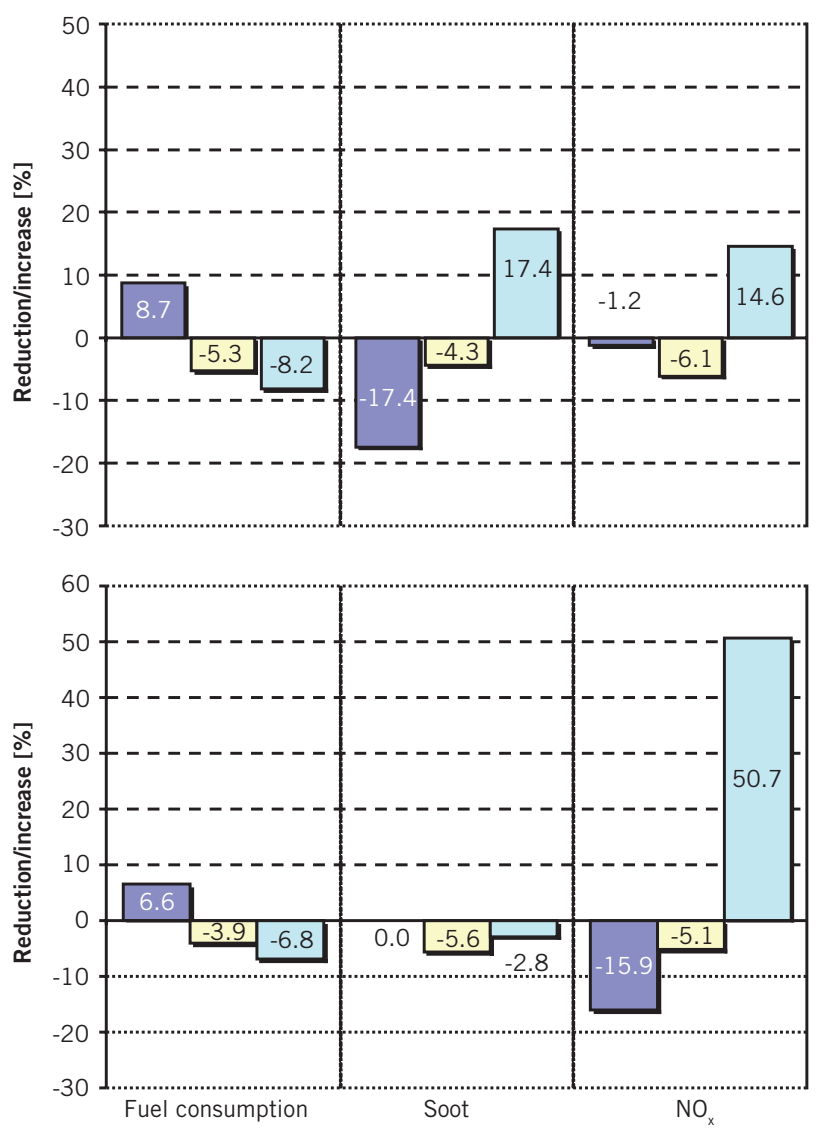

$\square$ 1.9-I Renault engine F9Q

$\square$ Derated Diesel Engine (DDE)

\section{Wybór objętości skokowej silnika a objętościowy wskaźnik mocy}

W niniejszej pracy przedstawiono wybór parametrów geometrycznych silnika dla danej kategorii pojazdu, rozważając różne cykle jezdne, ponieważ cykl NEDC (New European Driving Cycle) będzie zastąpiony testem WLTP (Worldwide Harmonized Light Vehicles Test Procedure). Ostateczny kształt nowego testu nie był znany w czasie, kiedy pisano niniejszą pracę. Opracowano zatem własny test, obejmujący w większym stopniu wysokie obciążenia i niestacjonarne warunki pracy niż test NEDC, odpowiadający przewidywanym trendom, które będą uwzględnione we wspomnianym nowym teście. Do analizy porównawczej wytypowano konwencjonalny silnik o pojemności 1,9 dm3, oznaczony F9Q, stosowany w pojazdach klasy Renault Laguna, wysokosprawny silnik DDE oparty na konstrukcji silnika Renault K9K (objętość skokowa 1,46 dm³), którego opis szczegółowy zamieszczono w następnym rozdziale, oraz silnik będący efektem downsizingu (ADD) - trzycylindrowy silnik o objętości skokowej $1,05 \mathrm{dm}^{3}$ i mocy $80 \mathrm{~kW}$. Wspomniany silnik wykorzystujący koncepcję downsizingu jest również efektem prac Renault, a szczegółowe informacje na jego temat przedstawiono $\mathrm{w}$ pracy [2].
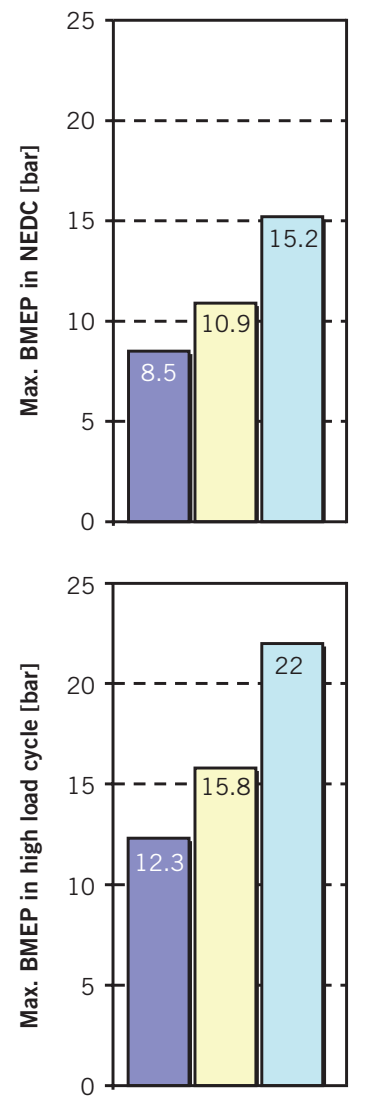

Symulacyjne porównanie parametrów pojazdu wyposażonego w każdy $\mathrm{z}$ wymienionych wyżej silników przedstawiono na rysunku 1. Bazę do porównań stanowi istniejący silnik K9K o pojemności $1,46 \mathrm{dm}^{3}$. Wszystkie przedstawione procentowe zmiany parametrów odnoszą się do osiągów tego silnika.

$\mathrm{Na}$ lewym górnym wykresie zaprezentowano wyniki w teście NEDC. Stosując wysokosprawny silnik ze zmniejszonymi stratami tarcia, zużycie paliwa można zredukować o 5,3\%, podczas gdy emisję sadzy i $\mathrm{NO}_{\mathrm{x}}$ odpowiednio o $4,3 \%$ i $6,1 \%$, przy stałej wartości objętości skokowej silnika. Dla silnika o pojemności $1,05 \mathrm{dm}^{3}$ uzyskuje się zmniejszenie zużycia paliwa o $8,2 \%$, podczas gdy emisja $\mathrm{NO}_{\mathrm{x}}$ i sadzy wzrasta znacząco z uwagi na zmianę obszaru pracy silnika, pomimo zastosowania emisyjnie zoptymalizowanej strategii spalania w obszarze wyższych obciążeń, uwzględniającej niskociśnieniowy EGR [3].
Fig.1. Engine concept comparison in the New European Driving Cycle (top) and in the higher loaded driving cycle (bottom)

Rys. 1. Porównanie wskaźników pojazdu wyposażonego w silniki różnej koncepcji w teście NEDC (górny wykres) i teście wysokich obciązeń (dolny wykres) 
significantly due to the shifting of the operation area. An emission optimized combustion strategy in the higher load area considering low pressure EGR [3] is already considered in this concept. In Fig. 1 (bottom) the simulation results for the higher loaded driving cycle are plotted. A significant increase in $\mathrm{NO}_{x}$ emissions and deterioration of the $\mathrm{NO}_{x} /$ soot trade-off can be seen at first glance while showing otherwise quite similar trends. This is due to the different characteristics of the driving cycles. The average power required for the given vehicle model amounts to $4.24 \mathrm{~kW}$ in the NEDC, while the value for the assumed future driving cycle goes up to $9.26 \mathrm{~kW}$, around double the value. The maximum engine load in the NEDC reaches 15.2 bar BMEP, while up to 22 bar are required in the high loaded cycle. These results collectively clearly indicate that aggressive downsizing concepts have to be seen critically in view of new, higher loaded driving profiles. At the same time it is seen that the efficiency engine can be an attractive approach not only in view of system costs.

\section{Prototype implementation of efficiency engine}

Having defined the system requirements, the next step towards engine hardware was to define the basic engine architecture and dimensions. Here a systematic approach, supported by experience (benchmarking) and simulation tools is applied to ensure that the system level targets are fulfilled. For the efficiency engine the focus was on minimizing the frictional losses from the cranktrain and the parasitic losses from oil and water pumps. The defined peak firing pressure for the DDE concept is only 110 bar; the gas forces are hence 30 to $40 \%$ lower than a typical state of the art Euro 5 diesel engine. A careful redesign of the complete cranktrain according to the lower loads was performed, tab. 1. Significant benefits are realized in terms of reduced mass and friction. At the pistons, the lower gas forces allow a reduction of piston pin diameter from 26 to $20 \mathrm{~mm}$. A reduction in wall thickness below the combustion bowl and the elimination of the piston cooling gallery due to the moderate specific power together permit a reduction in piston compression height to only $48 \%$ of the cylinder bore without requiring bearing bushes in the piston. The lower gas forces also allow a reduction in heights and tensions of the piston rings to a level more familiar from gasoline engines with corresponding reduction of friction. The small end of the connecting rod is redesigned to the reduced pin diameter and the shank crosssection adapted to the lower gas load. The big end is also reduced to suit the optimized crankpin diameter. The lower piston height allows an increase in conrod length of $5.25 \mathrm{~mm}$ which gives an additional friction benefit due to the reduction of side forces at the piston-liner interface. Nevertheless the weight of the conrod assembly was reduced by nearly $25 \%$. The application of cost-intensive sputter bearings at the big end could be avoided. At the crankshaft, the focus is on minimization of diameters of the main and crankpin bearings. In the first step, parameter variation was performed using FEM analysis of a single crankweb, based on a metric of bending deflection under gas load. The new layout was compared to a wide range of proven designs based on this
Na rysunku 1 (dolny wykres) przedstawiono wyniki symulacji dla własnego cyklu jezdnego wysokich obciążeń. Można zauważyć wzrost emisji NO i pogorszenie wskaźnika $\mathrm{NO}_{\mathrm{x}}$ /sadza. Powyższe zjawisko wynika z różnych charakterystyk cykli jezdnych. Średnia moc wymagana dla danego modelu pojazdu wynosi 4,24 kW w teście NEDC, podczas gdy we własnym teście wysokich obciążeń dochodzi do 9,26 kW. Maksymalne obciążenie silnika w teście NEDC, wyrażone jako średnie ciśnienie użyteczne, osiąga wartość 15,2 bar, a dla testu wysokich obciążeń dochodzi aż do 22 bar. Powyższe wyniki wskazują, że koncepcje agresywnego downsizingu muszą być poddane krytycznej ocenia z punktu widzenia nowych cykli jezdnych o wyższych obciążeniach niż w teście NEDC. Jednocześnie można zauważyć, iż wysokosprawny silnik może stanowić atrakcyjne rozwiązanie nie tylko ze względu na małe koszty systemu.

\section{Prototypowa implementacja wysokosprawnego silnika}

Dysponując zdefiniowanymi wymaganiami dla systemu, jako następny krok w budowie silnika określono architekturę i wymiary silnika. W tym celu zastosowano metodyczne podejście, wspomagane przez narzędzia empiryczne i symulacyjne, aby zapewnić zrealizowanie założonych celów dla systemu. W przypadku wysokosprawnego silnika istotne było zminimalizowanie strat tarcia w układzie korbowo-tłokowym i strat pomp oleju i cieczy chłodzącej.

Zdefiniowana wartość maksymalna ciśnienia spalania dla koncepcji DDE wynosi jedynie 110 bar, stąd siły gazowe są o 30 - 40\% mniejsze niż dla typowych współczesnych rozwiązań silników ZS klasy Euro 5. Z uwagi na wymienione mniejsze obciążenia, od nowa zaprojektowano układ korbowo-tłokowy tego silnika (tab. 1). Znaczące korzyści uzyskano dzięki redukcji masy i strat tarcia.

W odniesieniu do tłoków, mniejsze siły gazowe umożliwiają zmniejszenie średnicy sworznia tłokowego z $26 \mathrm{~mm}$ do $20 \mathrm{~mm}$. Redukcja grubości ścianki poniżej komory spalania i eliminacja chłodzenia tłoka z powodu zmniejszonych wartości mocy użytecznej pozwalają na redukcję wysokości sprężania do jedynie 48\% średnicy cylindra bez konieczności stosowania łożysk ślizgowych w tłoku.

Mniejsze siły gazowe umożliwiają ponadto zmniejszenie wysokości i naprężeń pierścieni tłokowych do poziomu bliskiego wartościom uzyskiwanym w silnikach ZI, wraz z odpowiadającą redukcją strat tarcia.

Głowa korbowodu jest zaprojektowana dla zredukowanej średnicy sworznia tłokowego, a przekrój poprzeczny trzonka zaadoptowany do mniejszych wartości obciążenia. Stopa korbowodu jest również zmodyfikowana dla właściwego połączenia ze zoptymalizowanym czopem korbowym. Mniejsza wysokość tłoka umożliwia wzrost długości korbowodu o 5,25 mm, co daje dodatkowe korzyści w zakresie tarcia, wynikające $\mathrm{z}$ redukcji bocznych sił na powierzchni tulei cylindrowej. Ciężar zespołu korbowodu zmniejszono o prawie $25 \%$. Nie było również konieczne stosowanie kosztownych napylanych łożysk ślizgowych. 
Table 1. Dimensions of cranktrain components

Tabela 1. Wymiary geometryczne elementów układu korbowo-tlokowego

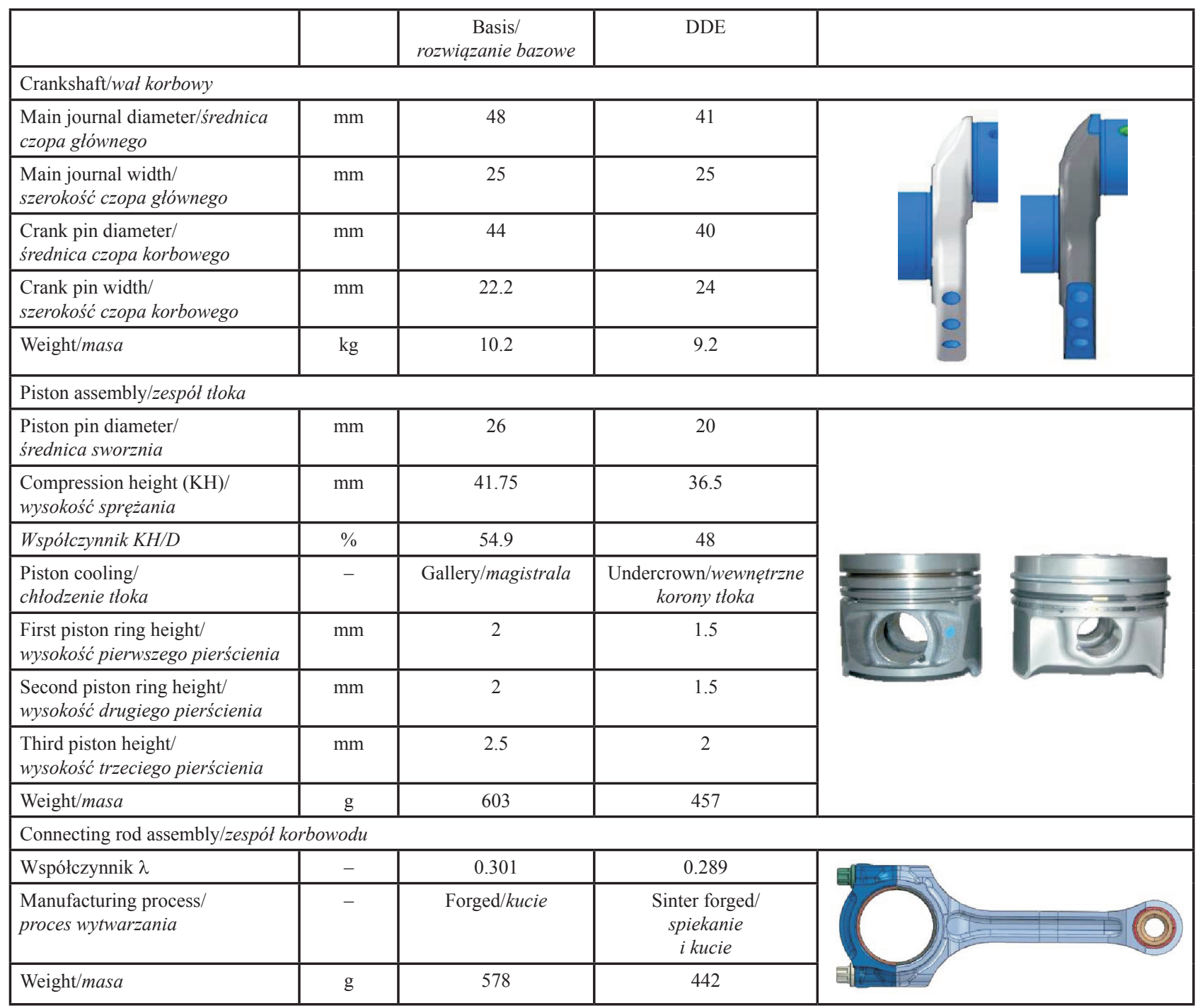

metric. The resulting layout was then validated using the full 3D Multi-Body-Simulation and Finite Element capabilities of AVL Excite, including elasto-hydrodynamic simulation of the bearings. It is noted that the crankshaft design is here limited by its stiffness - and hence the edge-loading of the main bearings - and not directly by the material fatigue strength as was the case for the ADD concept [2]. Including the proportional reduction of the counterweights, an overall saving in cranktrain mass of around $10 \%$ was achieved. The friction benefit of each of the measures described above was assessed individually with the help of simulation tools, Fig. 2 . The predicted reduction of 0.15 bar at $2000 \mathrm{rpm}$ compares very well with the strip-down measurements which have been performed with modified engine hardware based on the K9K engine. For further refinement of the friction prediction capabilities in future, AVL has developed a new one cylinder research engine which can measure frictional forces in the piston-liner interface under operating conditions up to 140 bar cylinder pressure and $4000 \mathrm{rpm}$ engine speed, Fig. 3. Since the mechanical loads on the DDE are comparable to
Odnośnie do wału korbowego, skupiono się na zmniejszeniu średnicy łożysk głównych i korbowodowych. Przede wszystkim analizowano zmiany parametrów pojedynczego ramienia wykorbienia $\mathrm{z}$ zastosowaniem metody elementów skończonych, bazując na strzałce ugięcia od zginania wskutek siły gazowej. Nowe rozwiązanie porównano do wcześniejszych sprawdzonych konstrukcji. Wynikowa konstrukcja była następnie poddana ocenie technicznej z zastosowaniem AVL Excite w obszarze pełnej trójwymiarowej symulacji i metody elementów skończonych, z uwzględnieniem elasto-hydrodynamicznej symulacji łożysk. Należy zauważyć, iż konstrukcja wału korbowego jest ograniczona jego sztywnością - i stąd obciążeniem brzegowym łożysk głównych, a pośrednio przez wytrzymałość zmęczeniową materiału, jak to miało też miejsce w przypadku koncepcji ADD [2]. Włączając proporcjonalne zmniejszenie masy przeciwciężarów, uzyskano całkowite zmniejszenie masy zespołu korbowego o $10 \%$.

Korzyści w obszarze strat tarcia każdego z opisanych rozwiązań oceniono indywidualnie z zastosowaniem narzę- 


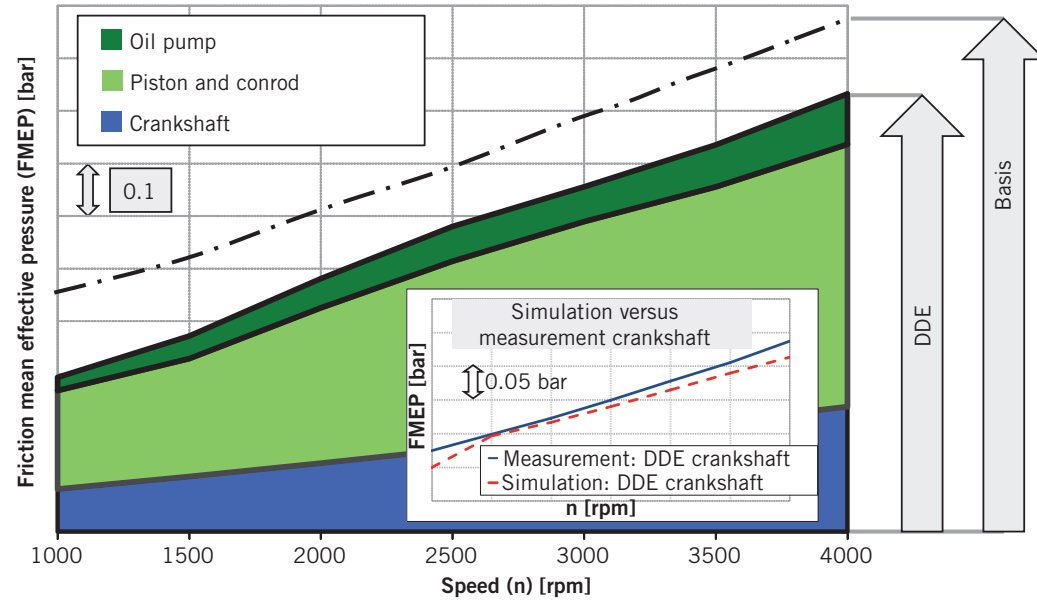

Fig. 2. Friction measurement and friction simulation Rys. 2. Przebiegi zmian średniego ciśnienia tarcia uzyskane w badaniach empirycznych i symulacyjnych

dzia symulacyjnego (rys. 2). Przewidywane zmniejszenie ciśnienia tarcia o 0,15 bar dla $\mathrm{n}=2000 \mathrm{obr} / \mathrm{min}$ jest porównywalne $\mathrm{z}$ dolnopasmowymi pomiarami przeprowadzonymi dla zmodyfikowanej konstrukcji silnika opartego na silniku K9K. W celu dalszego doskonalenia prognozowania zmian sił tarcia w przyszłości firma AVL skonstruowała jednocylindrowy silnik badawczy, w którym możliwy jest pomiar sił tarcia na powierzchni tulei cylindrowej aż do warunków pracy odpowiadających ciśnieniu w cylindrze równemu 140 bar i prędkości obrotowej silnika równej $4000 \mathrm{obr} / \mathrm{min}$. (rys. 3). Z uwagi na to, iż obciążenia mechaniczne dla silnika DDE są porównywalne do wysilonych turbodoładowanych silników GDI, koncepcja wpisuje się dobrze w rodzinę modułowych silników
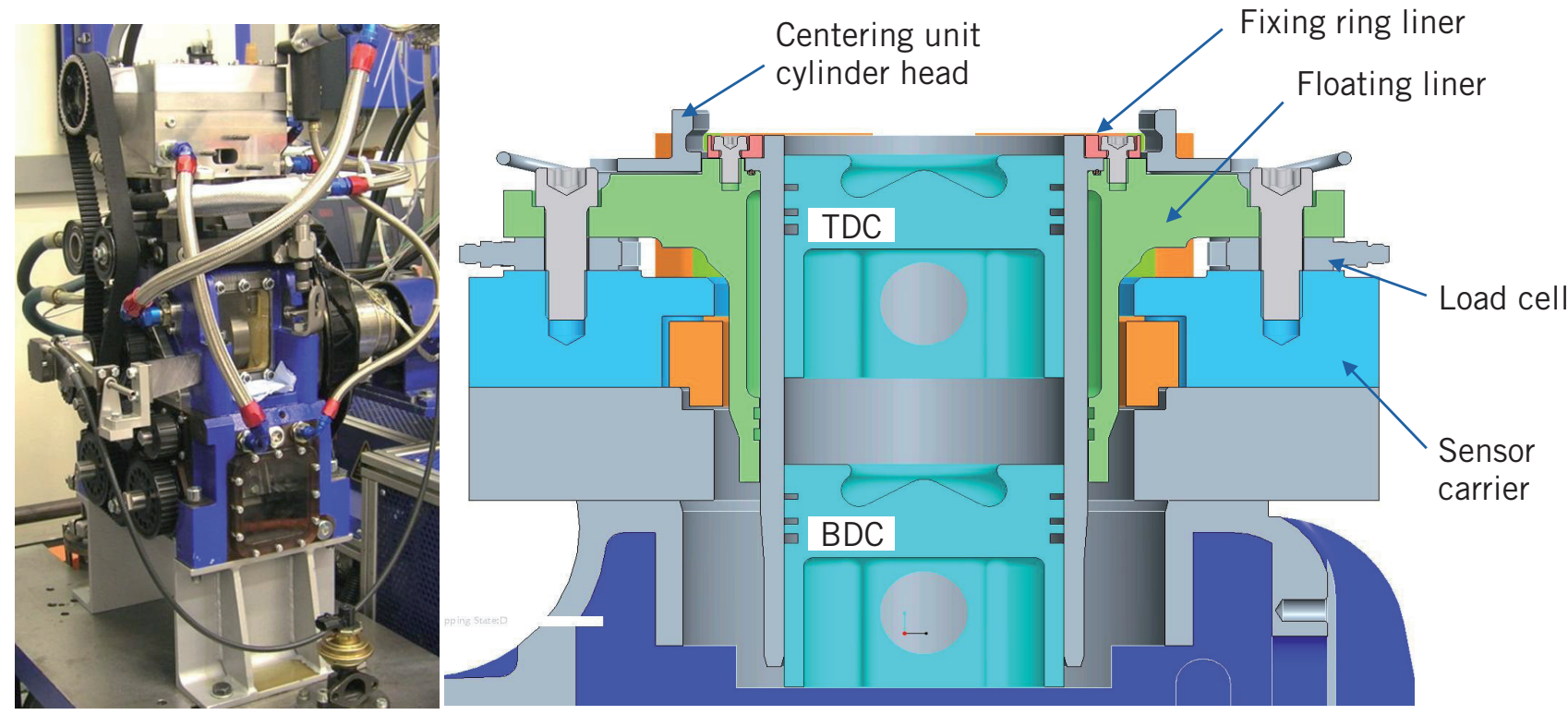

Fig. 3. Research engine for friction development

Rys. 3. Stanowisko do badań procesów tarcia $w$ silniku

a high performance turbocharged GDI engine, the concept fits well to a modular engine family line-up with common components and production facilities for diesel and gasoline variants [4].

\section{Measurement results}

After completion of the friction strip-down measurements, the efficiency engine was installed on the development testbed. In Figure 4 the part-load traces for $2000 \mathrm{rpm}$ are plotted. In the reference points at 2 bar BMEP an excellent brake specific fuel consumption below $290 \mathrm{~g} / \mathrm{kWh}$ in combination with attractive $\mathrm{NO}$ figures has already been achieved after a very short development period. At higher load areas the benefit in specific fuel consumption is reduced because the internal engine friction is not as dominant anymore. Compared to the scatter bands in grey color the excellent trade-off between fuel efficiency and $\mathrm{NO}_{\mathrm{x}}$ emission is evident. For ze wspólnymi elementami i urządzeniami produkcyjnymi dla wariantów silników ZS i ZI [4].

\section{Wyniki pomiarów}

Po ukończeniu pomiarów podstawowych w obszarze strat tarcia, na stanowisku badawczym zamontowano wysokosprawny silnik. Na rysunku 4 przedstawiono przebiegi dla obciążeń częściowych i prędkości obrotowej silnika 2000 obr/min. Przy wartości średniego ciśnienia użytecznego 2 bar uzyskano korzystne wartości emisji $\mathrm{NO}_{\mathrm{x}} \mathrm{i}$ jednostkowego zużycia paliwa (poniżej $290 \mathrm{~g} / \mathrm{kWh}$ ) już po krótkim okresie badań. Dla obszarów pracy silnika przy wyższych obciążeniach korzyści dotyczące jednostkowego zużycia paliwa są mniejsze z uwagi na mniejsze znaczenie tarcia wewnętrznego w silniku. W porównaniu do obszarów rozrzutu (o szarym kolorze) widać bardzo korzystne zmniejszenie zużycia paliwa i emisji $\mathrm{NO}_{x}$. Dalszą redukcję zużycia paliwa 


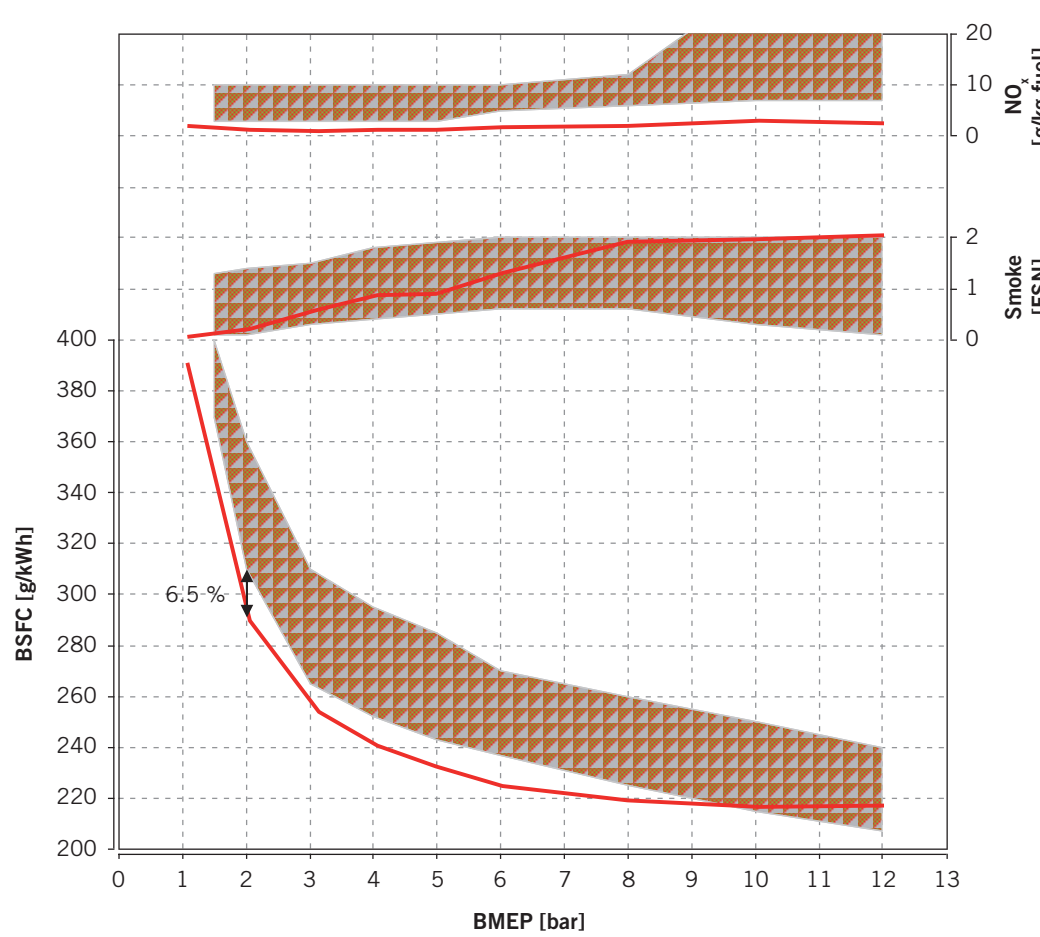

Fig. 4. Part load traces efficiency engine at $2000 \mathrm{rpm}$

Rys. 4. Przebiegi zmian parametrów wysokosprawnego silnika dla obciążeń częściowych i $n=2000 \mathrm{obr} / \mathrm{min}$

future developments, a further fuel consumption potential is seen by shooting for somewhat higher $\mathrm{NO}_{\mathrm{x}}$ emissions, assuming that $\mathrm{NO}_{\mathrm{x}}$ aftertreatment will be the main route for the Euro 6 fleet. For future planned vehicle application it can be assumed based on these early results that similarly attractive fuel efficiency figures as with a downsizing concept can be achieved; however with clearly reduced system costs.

\section{Summary and outlook}

With the derating approach (efficiency engine) also benefits with respect to system costs and complexity can be seen. The efforts for boosting, fuel injection system and NO aftertreatment are significantly reduced. This cost effective engine has the potential for highest production figures due to global market chances, thus offering additional benefits in the cost można uzyskać przez dopuszczenie nieco większej silnikowej emisji $\mathrm{NO}_{\mathrm{x}}$, zakładając, że pozasilnikowe systemy oczyszczania spalin z NO będą głównymi rozwiązaniami stosowanymi dla floty pojazdów spełniających normę Euro 6. Dla przyszłej planowanej aplikacji pojazdu można założyć, opierając się na wstępnych wynikach badań, iż, podobnie jak dla koncepcji downsizingu, można uzyskać korzystne zużycie paliwa, jednakże przy mniejszych kosztach systemu.

\section{Podsumowanie i perspektywy rozwoju}

W przypadku rozwiązania o mniejszych wartościach znamionowych parametrów silnika (silnik o wyższej sprawności) dostrzega się korzyści w zakresie kosztów systemu i jego mniejsze skomplikowanie. Zmniejszono znacząco wymagania w odniesieniu do systemu doładowania, układu zasilania i pozasilnikowego systemu oczyszczania spalin z $\mathrm{NO}_{\mathrm{x}}$. Powyższy, wydajny ekonomicznie silnik może być szeroko stosowany w produkcji z uwagi na możliwości światowego rynku. Nabywca będzie zadowolony z obniżonych kosztów obsługi i ze zwiększonego komfortu w porównaniu do koncepcji trzycylindrowego silnika, w którym uwzględniono proces downsizingu.

Opisany program obniżania wartości znamionowych parametrów silnika prowadzono przy współpracy z firmą

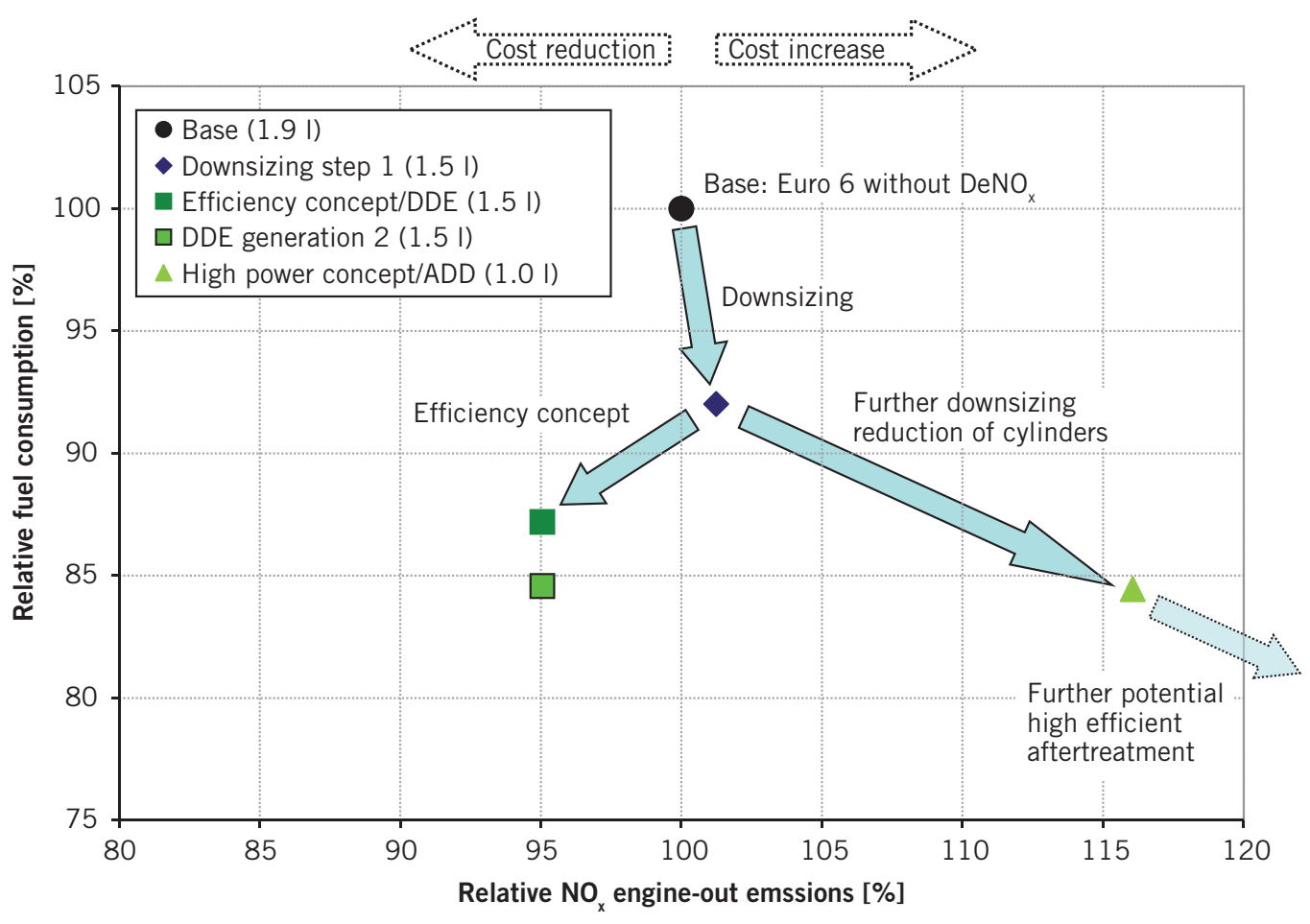

Fig. 5. Concept comparison with respect to $\mathrm{NO}_{\mathrm{x}}$ and fuel efficiency

Rys. 5. Porównanie różnych koncepcji silników pod względem emisji $\mathrm{NO}_{x}$ i zużycia paliwa 
structure. The customer will enjoy reduced maintenance costs and improved comfort compared to a three-cylinder downsizing concept. This derating program has been performed in close cooperation with Renault, taking the existing $1.461 \mathrm{~K} 9 \mathrm{~K}$ engine as base. In the derating program production boundaries of the existing facilities had to be considered; additional potential for the efficiency engine could be found if more freedom is available when defining a new engine family from scratch. Figure 5 summarizes the results collected. Downsizing promises lowest $\mathrm{CO}_{2}$ values when combined with a high efficiency $\mathrm{NO}_{\mathrm{x}}$ aftertreatment system. Current development is focussed on independent systems providing attractive reduction potential in an extended operation area. The biggest challenges at the moment are the system costs and further increased complexity. The efficiency/ derating concept currently offers an attractive solution for the cost sensitive high volume market combining improved fuel economy with system simplification and potential cost reduction, at the same time offering an attractive base for hybridisation.

\section{Acknowledgements}

Special Thanks to Mr. Philippe Mallet and Mr. Karim Ben-Cherif from Renault for their consistent support of the program. Further thanks to the colleagues Peter Gutmann, Ludwig Bürgler, Wolfgang Schnider and Bernhard Enzi.

Paper reviewed/Artykut recenzowany

Artykut w języku angielskim zostat takżę opublikowany $w$ MTZ nr 12/2011.

\section{Bibliography/Literatura}

[1] Weissbaeck M., Sorger H., Zieher F., Howlett M., Krapf S., Gutmann P.: Der Dieselmotor der Zukunft: Auslegung und Ergebnisse - Ausführungsbeispiele unter Berücksichtigung von Produktionsrandbedingungen. 19. Aachener Kolloquium Fahrzeug und Motorentechnik, 2010.

[2] Sorger H., Howlett M., Schnider W., Ausserhofer,N., Bartsch P., Weissbaeck M., Soustelle O.; Ragot, P.; Mallet, Ph.: The $\mathrm{CO}_{2}$ Challenge: Aggressive Downsizing for HSDI Diesel - Engine

Michael Weissbäck, Eng. - Deputy Vice President Passenger Car Diesel at AVL List GmbH, Graz, Austria.

Inż. Michael Weissbäck-zastępca dyrektora ds. samochodów osobowych z silnikami ZS w AVL List GmbH, Graz, Austria.

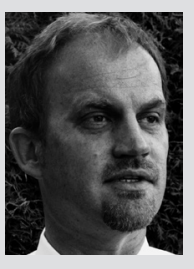

Mike Howlett, Eng. - Lead Engineer Passenger Car Engine Design at AVL List GmbH, Graz, Austria. Inż. Mike Howlett - Główny inżynier ds. konstrukcji silników do samochodów osobowych w AVL List GmbH, Graz, Austria.

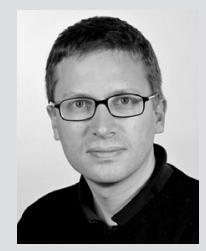

Renault, biorąc jako podstawę do badań silnik K9K o pojemności $1,46 \mathrm{dm}^{3}$. W programie wytwarzania bazującym na obniżaniu parametrów znamionowych silnika należy rozważyć granice obecnych systemów. Dodatkowy potencjał dla wysokosprawnego silnika może się pojawić, gdy dojdzie do tworzenia rodzin silników. Na rysunku 5 przedstawiono sumaryczne zestawienie uzyskanych wyników. Zastosowanie procesu downsizingu $\mathrm{w}$ silniku zapewnia najmniejsze wartości emisji $\mathrm{CO}_{2}$, gdy wraz z tym procesem zastosuje się systemy pozasilnikowej redukcji $\mathrm{NO}_{x}$ o dużej sprawności konwersji.

Obecny rozwój konstrukcji jest skupiony na niezależnych systemach zapewniających możliwości redukcji w rozszerzonych obszarach pracy silnika. Największe obecne wyzwania dotyczą kosztów systemu i jego dalej rosnącego skomplikowania. Obecnie koncepcja wysokosprawnego silnika (o zmniejszonych parametrach znamionowych) stanowi korzystne rozwiązanie dla wrażliwego cenowo rynku, łącząc poprawę zużycia paliwa z prostotą systemu i potencjalnym zmniejszeniem kosztów, przy jednoczesnym zapewnieniu korzystnej podstawy do zastosowania napędu hybrydowego.

\section{Podziękowania}

Autorzy dziękują Panom: Philippe Mallet i Karim BenCherif z firmy Renault za wsparcie programu badań. Wyrazy podziękowania składają również współpracownikom: Peterowi Gutmannowi, Ludwigowi Bürglerowi, Wolfgangowi Schneiderowi i Bernardowi Enzi.

Concept Definition. 31. Internationales Wiener Motorensymposium, 2010

[3] Weissbaeck M., Buergler L., Gutmann P.: Entwicklungstrends für den zukünftigen PKW Diesel Motor. 8. Dresdner Motorenkolloquium, 2009.

[4] Sorger H., Schoeffmann W., Howlett M.: The Internal Combustion Engine as Key Component. In: MTZ 72 (2011), No. 3.

Norbert Ausserhofer, Eng. - Lead Engineer Valve and Timing Drive Systems at AVL List GmbH, Graz, Austria.

Inż. Norbert Ausserhofer - Glówny inżynier ds. układów rozrządu silników w AVL List GmbH, Graz, Austria.

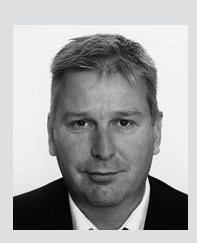

Stefan Krapf, Eng. - Senior Project Manager at AVL List GmbH, Graz, Austria.

Inż. Stefan Krapf-Glówny kierownik projektu w AVL List GmbH, Graz, Austria.

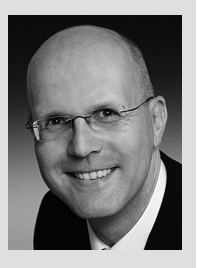

